\title{
PENGARUH PRODUK DOMESTIK BRUTO, SUKU BUNGA, KURS TERHADAP NERACA PERDAGANGAN DI INDONESIA
}

Asnawi $^{*{ }^{* a}}$, Hasniati ${ }^{* b}$

*Fakultas Ekonomi dan Bisnis Universitas Malikussaleh

a Corresponding author:asnawi@unimal.ac.id

b hasniati@gmail.com

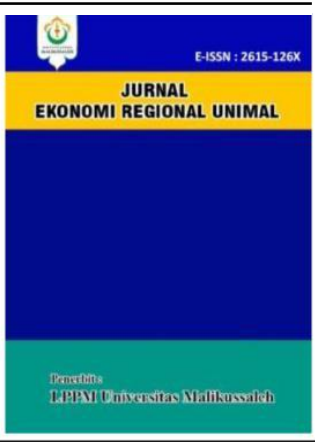

A R T I C L E I N F O R M A T I O N

A B S T R A C T

Keywords:

Gross Domestic Product

(GDP), Interest Rate,

Exchange Rate, Trade

Balance.
The study is conducted to determine the effect of Gross Domestic Product, Interest Rate, Exchange Rate on the Indonesian Trade Balance. The study uses time series data in the year 1986-2016 obtained from BPS and Bank Indonesia sites. The results meterest rate explained that Gross Domestic Product (GDP) and does not effect the trade balance. While the exchage rate has a positive and significant effect on the trade balance in Indonesia.

\section{PENDAHULUAN}

Pekembangan perekonomian suatu negara sekarang tidak terlepas dengan kondisi perekonomian global. Hubungan ekonomi antar negara menjadi faktor penting yang berpengaruh tehadap perkembangan ekonomi masing-masing negara. Pada masa ini tidak ada suatu negara pun yang berada dalam kondisi terisolasi tanpa adanya hubungan ekonomi dengan negara lain (Sa'idy, 2013). Kondisi ini mengakibatkan daya saing menjadi satu faktor pemicu yang utama sehingga antar negara mendapat manfaat dengan terbukanya perekonomian dunia (Astuti \& Dkk, 2015).

Perdagangan internasional merupaka cara yang ketetapan setiap negara yang memakai sistem perekonomian terbuka. Perdagangan internasional tampak dari aktivitas perdagangan barang serta jasa dana ktivitas investasi asing yang menyebabkan adanya arus masuk modal serta keluar modal. Seluruh transaksi dibukukan dalam neraca pembayaran internasional(Leonufna \& Dkk, 2016).

Perdagangan Internasional merupakan hal yang sudah mutlak dilakukan oleh setiap negara. Hal ini dikarenakan tidak ada satupun negara yang bisa memenuhi semua kebutuhannya secara mandiri (Rahmaddi, Rudi, \& Ichihasi, 2011). Terjadinya perdagangan internasional didasari karena ada perbedaan sumber daya yang ada oleh tiap wilayah atau negara. Serta kemampuan negara dalam menghasilkan barang serta jasa.

Sebagian negara-negara berkembang permintaan impor sering melampaui kapasitas mereka dalam menghasilkan pedapatan devisa. Hal ini telah menimbulkan masalah kronis pada neraca pembayaran. Oleh karena defisit pos neraca transaksi tidak bisa dihentikan dengan surplus pos neraca modal sehingga negara tersebut mencari tambahan utang ataupun pinjaman, khususnya dari luar negeri, untuk menutupi defisit neraca perdagangan tersebut. Ketidak satabilan neraca dalam perdagangan seperti yang terjadi pada negara sedang berkembang seperti Indonesia dapat disebabkan oleh beberapa faktor seperti Produk Domestik Bruto (PDB), suku bunga dan nilai tukar (kurs).

Penggunaan Produk Domestik Bruto (PDB) untuk penilaian neraca pembayaran adalah menggunakan PDB atas harga berlaku yang di dalamnya mencakup penambahan nilai ekspor dan pengurangan impor barang dan jasa sebagai komponen pembentuk neraca pembayaran. Sedangkan tingkat suku bunga merupakan suku bunga dalam negeri yang ditentukan Bank Indonesia. Kurs juga memerankan peran utama pada perdagangan internasional, disebabkan kurs 
dapat untuk membandingkan harga-harga barang serta jasa yang diproduksi oleh berbagai negara. Kondisi Produk Domestik Bruto (PDB), suku bunga, nilai tukar (kurs) dan neraca perdagangan Indonesia selama tiga periode terakhir dapat dilihat pada Tabel 1.1 berikut:

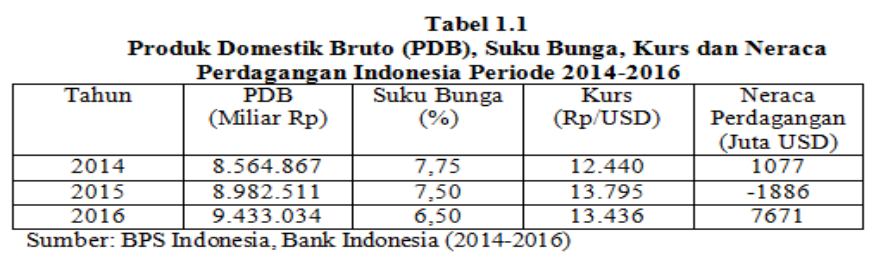

Dari tabel 1.1 dilihat bahwa terjadi kenaikan PDB pada tahun 2015 namun neraca perdagangan Indonesia justru memberikan efek negatif terhadap neraca perdagangan hingga mengalami defisit mencapai USD 1886 (dalam juta) padahal sebelumnya berada pada posisi surplus. Tahun 2014, PDB rendah dari tahun 2015 dan 2016 justru direspon positif oleh neraca perdagangan sebesar USD 1077 (dalam juta).

Demikian juga dengan suku bunga bank Indonesia, ketika turun pada level 7,50\%, neraca perdagangan Indonesia masih mengalami defisit. Pada tahun 2015 nilai tukar rupiah melemah, dapat menjadikan pihak asing membeli barang Indonesia dengan harganya murah. Keadaan ini akan membuat jumlah ekspor Indonesia meningkat. Apabila nilai ekspor besar dari nilai impor menandakan bahwa posisi neraca perdagangan Indonesia menunjukkan angka surplus, namun yang terjadi adalah neraca perdagangan menjadi defisit. Adapun tujuan dari penelitian ini adalah untuk mengetahui pengaruh produk domestik bruto, suku bunga, kurs terhadap neraca perdagangan di Indonesia.

\section{TINJAUAN PUSTAKA}

\subsection{Neraca Perdagangan}

Neraca perdagangan merupakan perbedaan diantara nilai ekspor serta impor suatu negara dalam waktu tertentu, diukur berdasarkan mata uang yang berlaku. Neraca positif yaitu terjadi surplus perdagangan apabila nilai ekspor tinggi dari impor, begitu sebaliknya neraca negatif. Neraca pedagangan dibagi menurut sektor barang serta sektor jasa (Safitri \& Dkk, 2014). Neraca perdagangan menyediakan informasi tentang ulasan dari performan perekonomian suatu negara dan juga pola perdaganagan sebagaimana tergambarkan dalam perdagangan barangnya.

\subsection{Produk Domestik Bruto}

Produk Domestik Bruto (PDB) merupakan jumlah nilai total dari seluruh produk yang dihasilkan oleh sektor-sektor produksi dengan pemanfaatan faktor produksi yang ada di wilayah pada periode tertentu, tanpa memperhatikan asal usul pelaku produksinya (BPS, 2014). Menurut BPS, (2014), cadangan dalam valuta asing ialah sumber terbesar bahan cadangan devisa Indonesia. Cadangan valas dibuat dari surat berharga danuang kertas asing serta simpanan.

\subsection{Suku Bunga.}

Suku bunga ialah rasio bunga atas jumlah pinjaman (Theo \& Juwita, 2014). Pada saat perusahaan mencanangkan memenuhi kebutuhan modal dipengaruhi tingkat bunga yang berlaku. Apakah akan menerbitkan sertifikat ekuaitas hutang.Suku bunga ialah harga atas dana yang dipinjam (Reilly \& Brown, 2004).

\subsection{Nilai Tukar Rupiah (Kurs).}

Menurut Adiningsih \& Dkk (2002), nilai tukar rupiah ialah harga rupiah atas mata uang asing. Nilaitukar rupiah ialah nilai satu mata rupiah yang ditukarkandengan mata uang negara lain. Misalnya; nilai tukar rupiah padaDolar AS, nilai tukar rupiah pada Yen. Ada dua pendekatan yang dipakaidalam memenuhi nilai tukar mata uang yang pendekatan moneter dan pendekatan pasar.

\section{METODE PENELITIAN}

\subsection{Objek dan Lokasi Penelitian}

Dalam penelitian ini, yang menjadi ruang lingkup penelitian adalah pengaruh Produk Domestik Bruto, Suku Bunga, Nilai Tukar (Kurs) terhadap Neraca Perdagangan. Lokasi penelitiannya adalah Indonesia.

\subsection{Jenis dan Sumber Data}

Jenis data yang digunakan data time series diperoleh dari publikasi Badan Pusat Statistik (BPS) Indonesia dan Bank Indonesia dalam rentang tahun 1986-2016 (30 tahun). 


\subsection{DefinisiOperasional Variabel}

Berdasarkan landasan teori, maka penulis menggunakan beberapa definisi operasional variabel sebagai berikut :

1. Produk Domestik Bruto (PDB) (X1), Produk Domestik Bruto (PDB) ialah nilai semua barang serta jasa secara bruto atas dasar harga konstan 2000 dan 2010 diproduksi dalam waktu tertentu (biasanya per tahun). Data PDB Dihitung dengan satuan Rupiah (Rp)

2. Suku bunga (X2), Suku bunga adalah sewa atas peminjaman uang melalui bank yang dinyatakan dalam persen (\%).

3. Kurs (Nilai Tukar Mata Uang) (X3),Nilai tukar rupiah ialah harga rupiah atas mata uang Dolar Amerika Serikat. Dihitung dengan satuan Rupiah (Rp)

4. Neraca Perdagangan (Y), Selisih nilai ekspor dengan impor non migas pada harga yang berlaku.Dihitung dengan satuan Dolar (USD).

\subsection{Metode Analisis Data}

Data yang didapat dari responden, kemudian di tabulasi dan diolah dengan memakai rumus persentase yang berguna untuk melihat kecenderungan-kecenderungan indikator dari masing-masing indikator. Selanjutnya untuk mengetahui apakah terdapat pengaruh signifikan dari variabel independen terhadap variabel dependen maka digunakan model regresi linier berganda (multiple linier regression method) diolah menggunakan aplikasi pengolah data statistik Eviews series 8.

$$
Y=\alpha+\beta_{1} X_{1}+\beta_{2} X_{2}+\beta_{3} X_{3}+e
$$

$\mathrm{Y}=$ Neraca Perdagangan

$\mathrm{X}_{1}=\mathrm{PDB}$

$\mathrm{X}_{2} \quad=$ Suku Bunga

$\mathrm{X}_{3} \quad=$ Kurs

$\alpha \quad=$ Konstanta

$\beta_{1}, \beta_{2}, \beta_{3}=$ Koefesien yang dicari

$$
\text { e } \quad=\text { standar error }
$$

4. HASIL PENELITIAN DAN PEMBAHASAN

\subsection{Hasil Uji Normalitas}

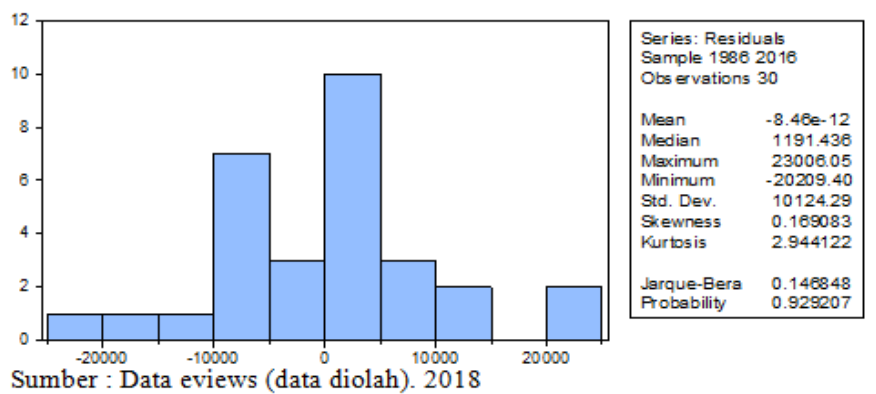

Gambar 1 Uji Normalitas

Untuk mengetahui normal serta tidak normalnya model regresi, variabel peganggu atau residual. Dengan cara membandingkan nilai J-B hitung dengan nilai $\mathrm{X}^{2}$ (Chi-Square) tabel. Nilai $\mathrm{X}^{2}$ tabel dengan $\mathrm{df}=32-3=29$. apabila dibandingkan dengan nilai Jarque-Bera pada gambar di atas sebesar 1.443337, maka disimpulkan bahwa model regresi, variabel peganggu atau residual terdistribusi normal karena nilai Jarque-Bera $<$ nilai $X^{2}$ tabel atau $1.443337<42.55697$ serta signifikansi sebesar $0.485967>0.05$. dengan demikian data terdistribusi normal.

\subsection{Hasil Uji Asumsi Klasik}

\subsubsection{Hasil Uji Autokorelasi}

Cara yang digunakan dalammengetahui ada serta tidaknya autokorelasi yaitu dengan Uji Durbin-Watson (DW test). Berikut hasil olah data untuk mendeteksi autokorelasi:

Tabel 2

Uji Autokorelasi Metode LM Test Breusch-Godfrey Serial Correlation LM Test:

\begin{tabular}{lrlr}
\hline \hline F-statistic & 1.491265 & Prob. F(2,21) & 0.2480 \\
Obs*R-squared & 3.357790 & Prob. Chi-Square(2) & 0.1866 \\
& & & \\
\hline \hline Sumber: Data eviews (data diolah) & &
\end{tabular}

Berdasarkan Tabel 2 di atas dapat dijelaskan bahwa nilai LM Test melalui $O b s^{*} R$-squared sebesar 3.357790 dengan Prob. Chi-Square(2) sebesar 0.1866 lebih besar dari 0.05. Dapat disimpulkan tidak terjadi autokorelasi dalam penelitian ini. 


\subsubsection{Hasil Uji Multikolinieritas}

Multikolonieritas ialahterdapat hubungan linier yang signifikan diantara beberapa variable independent model regresi. Apabila terjadi Multikolinieritas maka koefisien regresi menjadi tak tentu, tingkat kesalahannya besar serta biasanya ditandai dengan nilai koefisien determinasi yang besar.

\section{Tabel 3}

Hasil Uji Multikolinearitas

\begin{tabular}{ccccc}
\multicolumn{5}{c}{ Hasil Uji Multikolinearitas } \\
\hline NERACA_PERDANGANGAN & PDB & SUKU_BUNGA & KURS \\
\hline NERACA_PER & 1 & -0.4167 & 0.294 & 0.384 \\
DANGANGAN & -0.416 & 1 & -0.153 & -0.603 \\
PDB & 0.294 & -0.153 & 1 & 0.011 \\
SUKU_BUNGA & 0.384 & -0.603 & 0.011 & 1 \\
KURS & Sumber : Data Eviews (Data Diolah)
\end{tabular}

Pada tabel 3 diatas membuktikan dalam model regresi tidak terdapat multikolinearitas. Hal ini terlihat pada nilai korelasi tersebut di atas lebih kecil dari 0,8 .

\subsubsection{Hasil Uji Heteroskedastisitas}

Suatu penelitian dikatakan memiliki masalah heteroskedastisitas apabila nilai error atau residual model yang diteliti tidak mempunyai varian yang konstan dari satu arah ke arah yang lainnya. Hasil uji heteroskedastisitas berdasarkan uji White dapat diketahui pada tabel berikut :

\section{Tabel 4}

Uji Heteroskedastisitas

Heteroskedasticity Test: White

\begin{tabular}{llll}
\hline \hline F-statistic & 0.968281 & Prob. $F(9,20)$ & 0.4933 \\
Obs ${ }^{\star}$ R-squared & 9.104656 & Prob. Chi-Square(9) & 0.4277 \\
Scaled explained SS & 6.647546 & Prob. Chi-Square(9) & 0.6738 \\
\hline \hline
\end{tabular}

Sumber : Data Eviews (data diolah)

Berdasarkan tabel 4.9 di atas dapat kita lihat bahwa nilai probabilitas $O b s * R$-square sebesar 9.104656 dibandingkan dengan tingkat signifikansi (alpha). apabila nilai probabilitas signifikansi di atas 0,05 atau 0.4277 dapat disimpulkan tidak terjadinya heteroskedastisitas.

\subsection{Hasil Analisis Regresi Linier Berganda}

Setelah dilakukan analisis maka dapat dilakukan hasil regresi linier berganda. Hasil estimasi dapat diketahui pada Tabel 4.5 berikut:
Tabel 5

Regresi Linier Berganda

\begin{tabular}{lrrrr}
\hline \hline \multicolumn{1}{c}{ Variable } & Coefficient & Std. Error & t-Statistic & Prob. \\
\hline \hline C & -54370.37 & 29487.37 & -1.843853 & 0.0766 \\
LOG(PDB) & -1140.838 & 1049.435 & -1.087098 & 0.2870 \\
LOG(SUKU_BUNGA) & 7438.106 & 4312.225 & 1.724888 & 0.0964 \\
LOG(KURS) & 6155.215 & 2935.756 & 2.096637 & 0.0459 \\
\hline \hline R-squared & 0.391529 & Mean dependent var & 13800.47 \\
Adjusted R-squared & 0.321321 & S.D. dependent var & 12979.10 \\
S.E. of regression & 10692.44 & Akaike info criterion & 21.51603 \\
Sum squared resid & $2.97 E+09$ & Schwarz criterion & 21.70285 \\
Log likelihood & -318.7404 & Hannan-Quinn criter. & 21.57579 \\
F-statistic & 5.576688 & Durbin-Watson stat & 0.861022 \\
Prob(F-statistic) & 0.004321 & & & \\
\hline \hline
\end{tabular}

\section{Sumber : Data diolah 2018}

Hasil penghitungan dengan metode regresi dapat dilihat dalam persamaan jangka panjang berikut ini : $\mathrm{Y}=\mathrm{a}+\mathrm{bX} 1+\mathrm{bX}_{2}+\mathrm{bX}_{3}+\mathrm{e}$ $\mathrm{Y}=-54370.37-1140.838+7438.106+6155.215$

Dari formulasi model di atas menunjukkan bahwa nilai variabel konstanta sebesar -54370.37 yang berarti bahwa jika PDB, Suku Bunga dan Kurs nilainya 0, maka Neraca Perdagangan turun sebesar 54.370.37 USD. Nilai koefesien PDB sebesar 1140.838 yang berarti apabila PDB meningkat $1 \%$, maka akan menurunkan Neraca Perdagangan sebesar 1.140,838 USD Per Tahun.Nilai koefesien dari variabel suku bunga adalah sebesar 7.438.106 yang berarti apabila suku bunga meningkat1\%, maka akan menurunkan Neraca Perdagangan sebesar 7.438,106 USD. Nilai koefesien dari variabel kurs adalah sebesar 6155.215 yang berarti apabila nilai tukar Rupiah menguat 1 poin, maka akan meningkatkan Neraca Perdagangan sebesar $6.155,215$ USD.

Pada model di atas, dapat menunjukkan besarnya pengaruh variabel bebas secara bersamasama terhadap variabel terikatnya dengan melihat besarnya koefisien determinasi $\left(\mathrm{R}^{2}\right)$. Nilai $\mathrm{R}^{2}$ mempunyai interval 0 hingga $1\left(0 \leq \mathrm{R}^{2} \geq 1\right)$. Semakin besar $\mathrm{R}^{2}$,semakin baik hasil untuk model regresi tersebut jika mendekati 0 , maka variabel independen secara keseluruhan tidak bisa menjelaskan variabel independen (Wahid Sulaiman, 2004).

Nilai Adjusted $R$ Square pada tabel 4.7 sebesar 0.3213 atau 32,13\%. Artinya variabel independen yaitu PDB, Suku Bunga dan Kurs dapat menerangkan variabel dependen yaitu Neraca Perdagangan sebesar $32,13 \%$, sedangkan 
sisanya sebesar $67,87 \%$ diterangkan oleh variabelvariabel lain yang tidak di masukkan dalam model regresi pada penelitian ini.

\subsection{Hasil Pembuktian Hipotesis}

\subsubsection{Hasil Uji Parsial (t)}

Uji t digunakan melihat signifikansi dari pengaruh variabel independen secara individu terhadap variabel dependen yang menganggap variabel lain bersifat konstan. Uji (t) dilakukan dengan membandingkan $t$ hitung dengan $t$ tabel (Sulaiman, 2004). Untuk menguji pengaruh parsial bisa dilakukan melalui dua cara membandingkan nilai $\mathrm{t}$ hitung dalam tabel coefficients dengan $\mathrm{t}$ tabel. Jika $\mathrm{t}$ hitung $>\mathrm{t}$ tabel maka $\mathrm{H}_{1} \mathrm{H}_{2}$ dan $\mathrm{H}_{3}$ diterima maksudnyaada pengaruh secara parsial diantara variabel independen terhadap variabel dependen. Jika $\mathrm{t}$ hitung $<\mathrm{t}$ tabel maka $\mathrm{H}_{1} \mathrm{H}_{2}$ dan $\mathrm{H}_{3}$ ditolak artinya tidak terdapat pengaruh secara parsial diantara variabel independen terhadap variabel dependen.

Berdasarkan nilai probabilitas. Apabila nilai signifikansi kecil dari 0,05 atau 5\% maka hipotesis diterima atau signifikan. Apabila nilai signifikansi besar dari 0,05 atau 5\% sehingga hipotesis ditolak atau tidak signifikan.

Dari hasil perhitungan uji secara parsial antara PDB dengan Neraca Perdangan diperoleh nilai $\mathrm{t}$ hitung sebesar -1.087098 , serta $t_{\text {tabel }}$ sebesar 1.703 atau $(--1.087098<1.703)$ atau signifikansi signifikansi $\quad(0.2870>0,05) . \quad$ Karena nilai signifikansi besar daripada 0,05 serta nilai thitung lebih kecil dari $\mathrm{t}$ tabel disimpulkan bahwa PDB tidak berpengaruh terhadap Neraca Perdagangan maka hipotesis ditolak kebenarannya.

Dari hasil perhitungan uji secara parsial antara Suku Bunga dengan Neraca Perdangan diperoleh nilai $t$ hitung sebesar -0.741745 , serta $t_{\text {tabel }}$ sebesar 1.703 atau $(-0.741745<1.703)$ atau signifikansi signifikansi $(0.4644>0,05)$. Karena nilai signifikansi besar dari 0,05 dan nilai thitung kecil dari pada $\mathrm{t}$ tabel disimpulkan bahwa Suku Bunga tidak berpengaruh terhadap Neraca Perdagangan maka hipotesis ditolak kebenarannya.

Dari hasil perhitungan uji secara parsial antara Kurs dengan Neraca Perdangan diperoleh nilai $\mathrm{t}$ hitung sebesar 1.724888 , serta $\mathrm{t}_{\text {tabel }}$ sebesar 1.703 atau $(1.724888>1.703)$ atau signifikansi signifikansi $\quad(0.0964>0,05) . \quad$ Karena nilai signifikansi besar dari 0,05 serta nilai thitung kecil dari pada $\mathrm{t}$ tabel disimpulkan bahwa kurs tidak berpengaruh terhadap Neraca Perdagangan maka hipotesis ditolak kebenarannya.

\subsubsection{Hasil Uji Secara Serentak (Uji F)}

Uji $\mathrm{F}$ digunakan untuk melihat pengaruh variabel-variabel independen secara keseluruhan terhadap variabel dependen. Pengujian dilakukan dengan membandingkan nilai $F_{\text {hitung }}$ dengan $F_{\text {tabel }}$ (Sulaiman, 2004). Apabila nilai signifikansi kecil dari 0,05 atau $5 \%$ sehingga hipotesis diterima atau signifikan. Apabila nilai signifikansi lebih dari 0,05 atau $5 \%$ sehingga hipotesis ditolak atau tidak signifikan.

Berdasarkan Tabel 4.6 di atas dapat dilihat bahwa hasil uji $\mathrm{F}$ menunjukkan nilai $\mathrm{F}$ hitung sebesar 5.576688 dengan signifikansi sebesar 0.004321 . Nilai signifikansi tersebut lebih kecil daripada 0.05 disimpulkan bahwa variabel independen yaitu PDB, Suku Bunga dan Kurs secara simultan berpengaruh signifikan terhadap Neraca Perdaganganmaka hipotesis ditolak kebenarannya.

\subsection{Pembahasan}

\subsubsection{Pengaruh Produk Domestik Bruto Terhadap Neraca Perdagangan}

Berdasarkan hasil penelitian diketahui bahwa PDB tidak berpengaruh terhadap neraca perdagangan di Indonesia, hal ini berarti ketika Produk Domestik Bruto naik turun maka Neraca Perdagangan Indonesiatidak akan mengalami defisit. Ini terjadi karena produk domestik bruto mengalami peningkatan produksi nasional, hingga mendorong terjadinya ekspor, ketika terjadinya ekspor maka mampu meningkatkan posisi neraca perdagangan Indonesia.PenelitianEffendy (2014) dimana (PDB) berpengaruh negatif terhadap variabel neraca perdagangan.Hasil ini sejalan dengan penelitian Ramadhani \& Daulay (2015)di Indonesia dan di Turkey oleh Kayikci (2012)yaitu terdapat hubungan negatif antara PDB dengan neraca perdagangan.

\subsubsection{Pengaruh Suku BungaTerhadap NeracaPerdagangan}

Berdasarkan hasil penelitian diketahui bahwa suku bunga tidak berpengaruh terhadap 
neraca perdagangan di Indonesia. Kebijakan pemberian suku bunga dapat menimbulkan dampak pada kegiatan ekonomi karena Tingkat suku bunga tinggi mengakibatkancost of money mahal. Hal ini akan melemahkan daya saing ekspor dipasar dunia.Hasil penelitian ini relevan dengan penelitian Kusuma (2014) yang menyatakan tingkat bunga tidak berpengaruh terhadap fiuktuasi neraca perdagangan di Indonesia.

\subsubsection{Pengaruh Kurs Terhadap Neraca Perdagangan}

Berdasarkan hasil penelitian diketahui bahwa kurs berpengaruh terhadap neraca perdagangan di Indonesia, hal ini berarti ketika nilai tukar rupiah melemah atau depresiasi, maka bisa memperbaiki posisi neraca pembayaran Indonesia meskipun skalanya kecil. Sugema (2005)meneliti mengenai neraca pembayaran serta pengaruh nilai tukar terhadapnya di Indonesia. Hasil menunjukkan depresiasi nilai tukar dapatmemperbaiki neraca perdagangan riilmelalui ekspansi ekspor riil serta penurunan impor. Hasil lain menyimpulkan impor lebih sensitif tehadap depresiasi nilai tukar serta nilai ekspor tetap positif pada proses penyesuaian neraca perdagangan. Menunjukkan depresiasi nilai tukar dapat berpengaruh positif terhadap neraca pembayaran di Indonesia. Namun nilai kurs yang berpengaruh negatif terhadap neraca perdagangan Indonesia menyebabkan penurunan nilai ekspor ketika nilai tukar Rupiah terhadap dolar menurun.

\section{PENUTUP}

\subsection{Kesimpulan}

Berdasarkan hasil penelitian di atas dapat diambil beberapa kesimpulan sebagai berikut:

1. Produk Domestik Bruto (PDB) tidak berpengaruh terhadap neraca perdagangan di Indonesia.

2. Suku bunga tidak berpengaruh terhadap neraca perdagangan di Indonesia.

3. Kurs berpengaruh positif signifikan terhadap neraca perdagangan di Indonesia.

\subsection{Saran}

1. Pemerintah diharapkan lebih menjaga lagi nilai mata uang rupiah terhadap mata uang asing agar menciptakan iklim perekonomian yang stabil tanpa menimbulkan gejolak ketidakpastian akibat fluktuasi nilai mata uang. Meskipun neraca perdagangan tinggi, namun berdampak pada harga barang di dalam negeri.

2. Pemerintah Indonesia juga di harapkan untuk melindungi para pelaku usaha kecil menengah dari serbuan produk asing yang sifatnya non migas untuk dapat bersaing produknya di dunia internasional yang di mana ketika produk local Indonesia mendunia itu mampu mendatangkan devisa yang pada akhirnya memperbaiki neraca perdagangan.

3. Bagi pemerintah perlu mengambil kebijakan untuk mencapai keseimbangan eksternal seperti memperbaiki sektor perdagangan melalui peningkatan daya saing dan kualitas produk, yang bisa meningkatkan ekspor dalam rangka mengkoreksi defisit neraca transaksi perdagangan. Pemerintah juga dapat menggunakan kurs sebagai otoritas moneter serta menjaga pertumbuhan ekonomi sehingga pendapatan nasional dapat meningkat secara stabil.

\section{KEPUSTAKAAN}

Adiningsih, \& Dkk. (2002). Teori Ekonomi Mikro. Edisi Kedua. BPFE : Yogyakarta.

Astuti, I., \& Dkk. (2015). Pengelolaan Pendapatan Asli Desa (Studi Kasus Di Desa Ngombakan kecamatan Polokarto Kabupaten Sukaharjo 2014. Jurnal UMS: Surakarta.

Effendy, A. K. (2014). Analisa Neraca Pembayaran Indonesia dengan Pendekatan Keynesian dan Monetaris. Jurnal Ilmiah Fakultas Ekonomi Dan Bisnis Universitas Brawijaya, 2(2).

Ghozali, I. (2012). Aplikasi Analisis Multivariate Dengan Program SPSS. Badan Penerbit UNDIP: Semarang.

Kasmir. (2008). Bank dan Lembaga Keuangan Lainnya. Edisi Revisi 2008. PT Raja Grafindo Persada: Jakarta.

Kayikci, F. (2012). Determinans of the Current Accounts Balance in Turkey: Vector Auto Regression (VAR). Approach, 6(17).

Kusuma, R. I., \& Hakim, A. (2014). Kajian Empiris Fluktuasi Neraca Perdagangan 
Indonesia. Jurnal Fakultas Hukum:

Universitas Islam Indonesia.

Leonufna, L., \& Dkk. (2016). Analisis Pengaruh

Neraca Pembayaran Internasional

Terhadap Tingkat Kurs Rupiah/Dollar AS

Melalui Cadangan Devisa Dalam Sistem

Kurs Mengambang Bebas Di Indonesia

1998.1 sampai 2014.4. Jurnal FEB:

Universitas Sam Ratulangi, 16(2).

Rahmaddi, Rudi, \& Ichihasi, M. (2011). Export and Economics Growth in Indonesia: A Causality Approach Base on MultivariateError Correction Model. Journal of International Development and Cooperation, 17(2), 53-73.

Ramadhani, \& Daulay, M. (2015). Analisis Faktor-faktor yang mempengaruhi Transaksi Berjalan Indonesia Periode 2006-2013. Jurnal Ekonomi Dan Keuangan: Universitas Sumatra Utara, 2(10), 634-644.

Reilly, \& Brown. (2004). Investment Analysis and portfolio Management. Orlando: Druden Press.

Sa'idy, I. B. (2013). Dekomposisi Pertumbuhan Ekspor Tekstil dan Produk Tekstil Indonesia ke Amerika Serikat. JEJAK Journal of Economic and Policy, 6(1), 9-15.

Safitri, H., \& Dkk. (2014). Analisis Neraca Perdagangan Migas Dan Non Migas Indonesia Terhadap Volatilitas Cadangan Devisa 2003-2013. Jurnal FEB: Universitas Negeri Semaran, 3(2), 353-361.

Sugema, I. (2005). The determinants Of Trade Balance And Adjustment To The Crisis In Indonesia. Journal Of Economics and Policy, 8(2), 178-188.

Sulaiman, W. (2004). Analisis-Analisis Regresi Menggunakan SPSS.ANDI: Yogyakarta.

Theo, W., \& Juwita, R. (2014). Pengaruh Suku Bunga, Inflasi, Dan Pendapatan Nasional Terhadap Nilai Tukar Rupiah Tahun 2008-2012. STIE MDP. 